\title{
Edukasi Alat Penjernih Air Sederhana Sebagai Upaya Pemenuhan Kebutuhan Air Bersih
}

\author{
Budi Wicaksono ${ }^{1}$; Devita Mayasari ${ }^{2}$; Pratiwi Setyaning P³ ${ }^{3}$ Tommy Iduwin ${ }^{4}$; Tri Yuhanah ${ }^{5}$

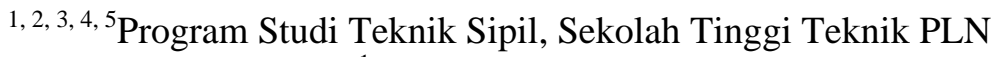 \\ ${ }^{1}$ budi@sttpln.ac.id
}

\begin{abstract}
Water is source of life on earth. The largest water body is in the ocean at 97 percent and 3 percent remaining is fresh watter which is used to support daily needs, so clean water is a basic human need. The limited amount of water and increasing people number caused a clean water crisis. Apart from the amount, the quality of fresh water is getting worse. The struggle to use clean water for various uses and clean water wasteful behavior had resulted in the loss of adequate access of clean water for some people. One of the ways to improve clean water quality and quantity is conducting a water purification process. Water purification can be done using simple tools with filtration techniques. Through the Community Partnership Program's theme "Education of Simple Water Purification as an Effort to Fulfill Clean Water Needs" able to provide knowledge and understanding to teachers and students of MTs Nurul Qur'an Jakarta as activity partners.
\end{abstract}

Keywords: clean water, filtration, water purification

\begin{abstract}
ABSTRAK
Air merupakan sumber bagi kehidupan di muka bumi. Badan air terbesar terdapat di laut sebesar 97 persen dan sisanya sebesar 3 persen adalah air tawar yang digunakan untuk menunjang kebutuhan sehari-hari sehingga air bersih menjadi kebutuhan dasar manusia. Jumlah air yang terbatas dan semakin banyak jumlah manusia menyebabkan terjadinya krisis air bersih. Selain jumlahnya, kualitas air tawar yang ada semakin rusak. Perebutan penggunaan air bersih untuk berbagai penggunaan menyebabkan hilangnya akses yang layak terhadap air bersih bagi sebagian orang. Perilaku boros air bersih menyebabkan semakin banyaknya orang yang kehilangan akses terhadap air bersih. Salah satu cara untuk meningkatkan kualitas air dan kuantitas air bersih, yaitu dengan melakukan proses penjernihan air. Penjernihan air dapat dilakukan menggunakan alat yang sederhana dengan teknik filtrasi. Melalui kegiatan Program Kemitraan Masyarakat dengan tema "Edukasi Alat Penjernih Air Sederhana Sebagai Upaya Pemenuhan Kebutuhan Air Bersih" mampu memberikan pengetahuan dan pemahaman kepada para guru dan siswa MTs Nurul Qur'an Jakarta sebagai mitra kegiatan.
\end{abstract}

Kata kunci: air bersih, filtrasi, penjernihan air 


\section{PENDAHULUAN}

\subsection{Analisis Situasi}

Air menutupi hampir $71 \%$ permukaan bumi dengan sebagian besar terdapat di laut dan pada lapisan- lapisan es di kutub, serta sisanya terdapat pada awan, hujan, sungai, muka air tawar, dan uap air. Air dalam obyek-obyek tersebut bergerak mengikuti suatu siklus air, yaitu: melalui penguapan, hujan, dan aliran air di atas permukaan tanah (runoff, meliputi mata air, sungai) menuju laut. Badan air terbesar terdapat di laut sebesar $97 \%$ dan 3\% sisanya adalah air tawar yang digunakan sebagai penunjang kehidupan sehingga air bersih menjadi kebutuhan dasar manusia ${ }^{[1]}$. Macam-macam air dan pembagiannya antara lain ${ }^{[2]}$ :

1. Air permukaan, yaitu air hujan yang mengalir di atas permukaan bumi dikarenakan tidak mampu terserap ke dalam tanah (lapisan tanah bersifat rapat air) sehingga sebagian besar air akan tergenang dan cenderung mengalir menuju daerah yang lebih rendah. Contoh air permukaan antara lain air sungai, air danau, dan air laut.

2. Air angkasa, yaitu air yang berasal dari udara atau atmosfer yang jatuh ke permukaan bumi. Komposisi air yang terdapat di lapisan udara berkisar $0,001 \%$ dari total air yang ada di bumi. Contoh air angkasa antara lain air hujan, air salju, dan air es.

3. Air tanah, yaitu segala macam jenis air yang terletak di bawah lapisan tanah dan menyumbang sekitar $0,6 \%$ dari total air di bumi. Hal ini menjadikan air tanah lebih banyak daripada air sungai dan danau apabila digabungkan meupun air yang terdapat di atmosfer. Pengelompokkan air tanah menurut letaknya terbagi menjadi:

a. Air tanah freatik, yaitu air tanah dangkal yang berada tidak jauh dari permukaan tanah sekitar 9-15 meter di bawah permukaan tanah. air tanah dangkal umumnya bening, namun pada beberapa tempat air freatik ini dapat tercemar seperti memiliki kandungan $\mathrm{Fe}$ dan $\mathrm{Mn}$ yang tinggi

b. Air tanah artesis, yaitu air tanah dalam yang terletak di bawah lapisan tanah kedap air pertama dengan kedalaman sekitar 80-300 meter. Kualitas air lebih baik dibandingkan air tanah dangkal.

c. Air tanah meteorit (Vados), yaitu air tanah yang berasal dari hujan/presipitasi sebelum terjadi proses kondensasi air di atmosfer dan tercampur dengan debu meteor. Perlu diketahui bahwa setiap saat meteor berukuran kecil bergesekan dengan atmosfer dan habis sebelum mencapai permukaan bumi.

Air memiliki karakteristik yang khas yang dapat berupa karakteristik fisik dan kimiawi. Karakteristik fisik air terdiri dari kekeruhan, temperatur, warna, kandungan zat padat, bau, dan rasa. Sedangkat karekteristik kimiawi air terdiri dari pH, DO (Dissolved Oxygent), BOD (Biological Oxygent Demand), COD (Chemical Oxygent Demand), kesadahan, dan senyawa-senyawa kimia beracun seperti Fe dan Mn.

Air bersih merupakan salah satu jenis sumber daya berbasias air yang bermutu baik dan biasa dimanfaatkan oleh manusia untuk dikonsumsi atau dalam melakukan aktivitas sehari-hari. Karakteristik air bersih antara lain:

1. Jernih, tidak berbau, dan tidak berwarna

2. Suhunya sebaiknya sejuk dan tidak panas

3. Bebas unsur-unsur kimia yang berbahaya seperti besi $(\mathrm{Fe})$, seng $(\mathrm{Zn})$, raksa $(\mathrm{Hg})$, dan mangan $(\mathrm{Mn})$.

4. Tidak mengandung unsur mikrobiologi yang membahayakan seperti coli dan total coliforms. 
Terang : Jurnal Pengabdian Pada Masyarakat Menerangi Negeri

e-ISSN: 2655-5948

Vol. 2, No. 1, Desember 2019

DOI: https://doi.org/10.33322/terang.v2i1.536

Air bersih yang dapat dimanfaatkan disarankan agar memenuhi standar baku mutu air sebagai persyaratan kualitas air bersih ${ }^{[3]}$.

Tabel 1. Daftar Persyaratan Kualitas Air Bersih

\begin{tabular}{|c|c|c|c|c|}
\hline No. & PARAMETER & Satuan & $\begin{array}{c}\text { Kadar Maksimum } \\
\text { yang } \\
\text { diperbolehkan }\end{array}$ & Keterangan \\
\hline 1 & 2 & 3 & 4 & 5 \\
\hline A. & EISIKA & & & \\
\hline 1. & Bau & - & - & Tidak berbau \\
\hline 2. & Jumlah zat padat & 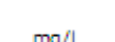 & 1000 & . \\
\hline 3. & Kekeruhan & Skala NTU & 5 & : \\
\hline 4. & Rasa & - & . & Tidak berasa \\
\hline $\begin{array}{l}5 . \\
6 .\end{array}$ & $\begin{array}{l}\text { Suhu } \\
\text { Warna }\end{array}$ & $\begin{array}{l}{ }^{\circ} \mathrm{C} \\
\text { Skala TCu }\end{array}$ & Suhu udara $\pm 3^{\circ} \mathrm{C}$ & - \\
\hline B. & KIMIA & & & \\
\hline a. & Kimia Anorganik & & & \\
\hline 1. & Air raksa & $\mathrm{mg} / \mathrm{L}$ & 0,001 & \\
\hline 2. & Alumunium & $\mathrm{mg} / \mathrm{L}$ & 0,2 & \\
\hline 3. & Arsen & $\mathrm{mg} / \mathrm{L}$ & 0,05 & \\
\hline 4. & Barium & $\mathrm{mg} / \mathrm{L}$ & 1,0 & \\
\hline 5. & Besi & $\mathrm{mg} / \mathrm{L}$ & 0,3 & \\
\hline 6. & Fluorida & $\mathrm{mg} / \mathrm{L}$ & 1,5 & \\
\hline 7. & Kadnium & $\mathrm{mg} / \mathrm{L}$ & 0,005 & \\
\hline 8. & Kesadahan ( $\mathrm{CaCO} 3)$ & $\mathrm{mg} / \mathrm{L}$ & 500 & \\
\hline 9. & Klorida & $\mathrm{mg} / \mathrm{L}$ & 250 & \\
\hline 10. & Kromium, Valensi 6 & $\mathrm{mg} / \mathrm{L}$ & 0,05 & \\
\hline 11. & Mangan & $\mathrm{mg} / \mathrm{L}$ & 0,1 & \\
\hline 12. & Natrium & $\mathrm{mg} / \mathrm{L}$ & 200 & \\
\hline 13. & Nitrat, sebagai $\mathrm{N}$ & $\mathrm{mg} / \mathrm{L}$ & 10 & \\
\hline 14. & Nitrit, sebagai N & $\mathrm{mg} / \mathrm{L}$ & 1,0 & \\
\hline 15. & Perak & $\mathrm{mg} / \mathrm{L}$ & 0,05 & \\
\hline 16. & & - & $6,5-8,5$ & Merupakan batas minimum \\
\hline 17. & Selenium & $\mathrm{mg} / \mathrm{L}$ & 0,01 & \\
\hline 18. & Seng & $\mathrm{mg} / \mathrm{L}$ & 5,0 & \\
\hline 19. & Sianida & $\mathrm{mg} / \mathrm{L}$ & 0,1 & \\
\hline 20. & Sulfat & $\mathrm{mg} / \mathrm{L}$ & 400 & \\
\hline 21. & Sulfida (sebagai H2S) & $\mathrm{mg} / \mathrm{L}$ & 0,05 & \\
\hline 22. & Tembaga & $\mathrm{mg} / \mathrm{L}$ & 1,0 & \\
\hline 23. & Timbal & $\mathrm{mg} / \mathrm{L}$ & 0,05 & \\
\hline b. & Kimia Organik & & & \\
\hline 1. & Aldrin dan Dieldrin & $\mathrm{mg} / \mathrm{L}$ & 0,0007 & \\
\hline 2. & Benzena & $\mathrm{mg} / \mathrm{L}$ & 0,01 & \\
\hline 3. & Benzo (a) pyrene & $\mathrm{mg} / \mathrm{L}$ & 0,00001 & \\
\hline 4. & $\begin{array}{l}\text { Chlordane (total } \\
\text { isomer) }\end{array}$ & $\mathrm{mg} / \mathrm{L}$ & 0,0003 & \\
\hline 5. & Coloroform & $\mathrm{mg} / \mathrm{L}$ & 0,03 & \\
\hline 6. & $2,4 \mathrm{D}$ & $\mathrm{mg} / \mathrm{L}$ & 0,10 & \\
\hline 7. & DDT & $\mathrm{mg} / \mathrm{L}$ & 0,03 & \\
\hline 8. & Detergen & $\mathrm{mg} / \mathrm{L}$ & 0,05 & \\
\hline 9. & 1,2 Discloroethane & $\mathrm{mg} / \mathrm{L}$ & 0,01 & \\
\hline 10. & 1,1 Discloroethene & $\mathrm{mg} / \mathrm{L}$ & 0,0003 & \\
\hline 11. & Heptaclor dan & & 20 & \\
\hline & heptaclor epoxide & $\mathrm{mg} / \mathrm{L}$ & 0,003 & \\
\hline 12. & Hexachlorobenzene & $\mathrm{mg} / \mathrm{L}$ & $\begin{array}{l}0,00001 \\
0,004\end{array}$ & \\
\hline 14. & $\begin{array}{l}\text { Gamma-HCH (Lindane) } \\
\text { Methoxychlor }\end{array}$ & $\begin{array}{l}\mathrm{mg} / \mathrm{L} \\
\mathrm{mg} / \mathrm{L}\end{array}$ & 0,03 & \\
\hline 15. & Pentachlorophanol & $\mathrm{mg} / \mathrm{L}$ & 0,01 & \\
\hline
\end{tabular}

\begin{tabular}{|c|c|c|c|c|}
\hline No. & PARAMETER & Satuan & $\begin{array}{c}\text { Kadar Maksimum } \\
\text { yang } \\
\text { diperbolehkan }\end{array}$ & Keterangan \\
\hline 1 & 2 & 3 & 4 & 5 \\
\hline $\begin{array}{l}16 . \\
17 . \\
18 .\end{array}$ & $\begin{array}{l}\text { Pestisida Total } \\
2,4,6 \text { urichlorophenol } \\
\text { Zat organik (KMnO4) }\end{array}$ & $\begin{array}{l}\mathrm{mg} / \mathrm{L} \\
\mathrm{mg} / \mathrm{L} \\
\mathrm{mg} / \mathrm{L}\end{array}$ & $\begin{array}{l}0,10 \\
0,01 \\
10\end{array}$ & \\
\hline $\begin{array}{l}\text { C. } \\
1 .\end{array}$ & $\begin{array}{l}\text { Mikro biologik } \\
\text { Koliform Tinja }\end{array}$ & $\begin{array}{l}\text { Jumlah per } 100 \\
\text { ml }\end{array}$ & 0 & \\
\hline 2. & Total koliform & $\begin{array}{l}\text { Jumlah per } 100 \\
\mathrm{ml}\end{array}$ & 0 & $\begin{array}{l}95 \% \text { dari sampel yang } \\
\text { diperiksa selama setahun. } \\
\text { Kadang-kadang boleh ada } \\
3 \text { per } 100 \mathrm{ml} \text { sampel air, } \\
\text { tetapi tidak berturut-turut }\end{array}$ \\
\hline $\begin{array}{l}\text { D. } \\
1 . \\
2 .\end{array}$ & $\begin{array}{l}\text { Radio Aktivitas } \\
\text { Aktivitas Alpha } \\
\text { (Gross Alpha Activity) } \\
\text { Aktivitas Beta } \\
\text { (Gross Beta Activity) } \\
\end{array}$ & $\begin{array}{l}\mathrm{Bq} / \mathrm{L} \\
\mathrm{Bq} / \mathrm{L}\end{array}$ & $\begin{array}{l}0,1 \\
1,0\end{array}$ & \\
\hline
\end{tabular}

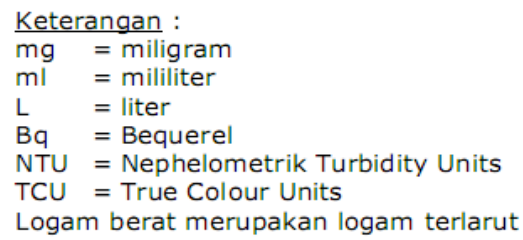

(Sumber: Peraturan Menteri Kesehatan No. 416, 1990) 
Teknik pengolahan air yang sering digunakan untuk mendapatkan air bersih sesuai dengan standar mutu diantaranya ${ }^{[4]}$ :

1. Teknik koagulasi, yaitu teknik pengolahan air yang diterapkan dengan bantuan koagulan kimia seperti Polyelektrolit (misalnya: PAC atau Poly Aluminium Chloride, PAS atau Poly Aluminium Sulfat), garam aluminat (misalnya: alum, tawas), garam $\mathrm{Fe}$, khitin, dan sebagainya.

2. Teknik redoks yaitu teknik pengolahan air yang diterapkan dengan bantuan inhibitor seperti senyawa khlor (misalnya: kaporit), non khlor atau teknik redoks lainnya.

3. Bioremoval dan Bioremidiasi merupakan teknik pengolahan air dengan menggunakan biomaterial. Biomaterial tersebut antara lain lumut, daun teh, sekam padi, dan sabut kelapa sawit, atau juga dari bahan non biomaterial seperti perlit, tanah gambut, lumpur aktif dan lain-lain.

4. Reverse osmosis yaitu teknik pengolahan air yang merupakan kebalikan dari proses osmosis alami. Osmosis adalah perpindahan cairan dari konsentrasi rendah ke konsentrasi tinggi yang melewati membran semipermeabel.

5. Teknik filtrasi atau penyaringan yaitu teknik pengolahan air yang diterapkan dengan bantuan media filter seperti pasir (misalnya: silika, antrasit), senyawa kimia atau mineral (misalnya: kapur, zeolit, karbon aktif, resin, ion exchange), membran, biofilter atau teknik filtrasi lainnya.

Sistem penyaring air sederhana adalah sistem yang paling banyak digunakan baik itu kegunaan rumah tangga hingga kegunaan Industri. Media saringan berfungsi sebagai penyaring yang terdiri dari media filtrasi dan media penyangga. Media penyangga yang umumnya dipakai umumnya adalah kerikil, sabut kelapa, arang, ijuk dan spons. Sedangkan media filtrasi bisa menggunakan single-media berupa pasir silica, atau dual-media yaitu pasir dan karbon aktif (umumnya digunakan antrasit).

Kegiatan edukasi alat penjernih air sederhana sebagai upaya pemenuhan kebutuhan air bersih ini menggunakan teknik filtrasi dengan memperlambat aliran. Air keruh melewati penjernih air sederhana akan tersaring sehingga menghasilkan air yang jernih. Media yang digunakan pada alat penjernih air sederhana antara lain filter akuarium, sabut kelapa, ijuk, arang, kerikil, dan pasir. Masing-masing media tersebut memiliki kegunaan pada proses penjernihan air. Kerikil berfungsi menyaring material berukuran besar, arang berfungsi sebagai karbon aktif yang dapat menghilangkan bau dan warna, serta pasir dan filter akuarium berfungsi untuk menyerap endapan-endapan.

MTs Nurul Qur'an yang terletak di Jl. Raya Duri Kosambi No. 7 RT.13/RW. 7 Duri Kosambi, Cengkareng, Jakarta Barat merupakan sekolah yang menjadi sasaran mitra kegiatan PKM tentang edukasi alat penjernih air sederhana sebagai upaya pemenuhan kebutuhan air bersih. Setelah dikonsultasikan dengan pihak mitra diketahui bahwa alat tersebut masih belum diedukasikan. Melalui hasil PKM diharapkan sekolah - sekolah memahami dan mengerti tentang proses penjernihan air.

\subsection{Permasalahan Mitra}

Mitra masyarakat yang bekerjasama melaksanakan Program Kemitraan Masyarakat (PKM) dengan tim pengusul adalah MTs Nurul Qur'an yang berlokasi di Jl. Raya Duri Kosambi No. 7 RT. 13/RW. 7 Duri Kosambi, Cengkareng, Jakarta Barat. Setelah dilakukan kunjungan ke lokasi Mitra diketahui bahwa pengetahuan para siswa dan guru tentang proses penjernihan air masih minim. Hal ini perlu segera diatasi dengan diadakannya kegiatan edukasi kepada para siswa dan guru untuk meningkatkan pengetahuan mengenai proses penjernihan air sebagai upaya pemenuhan kebutuhan 
air bersih. Setelah diadakannya kegiatan PKM ini, diharapkan peserta kegiatan PKM dapat mengenal dan memahami:

1. Pembagian dan macam-macam air di bumi, karakteristik air bersih dan teknik pengolahan air

2. Keberadaan standar baku mutu air sebagai persyaratan kualitas air bersih.

3. Alasan pentingnya dalam mengenal dan memahami proses penjernihan air sebagai upaya pemenuhan kebutuhan air bersih

4. Fungsi dan manfaat dari alat penjernih air sederhana dalam kehidupan sehari-hari

5. Kegunaan mengenal dan memahami tentang alat penjernih air sederhana.

\section{METODE}

\subsection{Sifat dan Bentuk Kegiatan}

Edukasi alat penjernihan air sederhana sebagai upaya pemenuhan kebutuhan air bersih Jakarta akan dilaksanakan di MTs Nurul Qur'an dalam satu sesi dan diikuti oleh 95 peserta. Kegiatan ini akan dilaksanakan dalam waktu satu hari kerja. Setiap peserta akan diberikan materi tentang alat penjernih air sederhana sebagai upaya pemenuhan kebutuhan air bersih. Berikut adalah langkahlangkah kegiatan yang dilakukan pada mitra:

Langkah 1 : Peserta melakukan pre test mengenai topik yang akan disampaikan.

Langkah 2 : Peserta edukasi diberikan teori dan pemahaman tentang proses penjernihan air sebagai upaya pemenuhan kebutuhan air bersih serta melakukan praktek pembuatan alat penjernih air sederhana.

Langkah 3 : Peserta diberikan kesempatan bertanya kepada presentator.

Langkah 4 : Peserta melakukan post test mengenai topik yang telah disampaikan.

\subsection{Diagram Alir Kegiatan}

Kegiatan PKM mengikuti acuan diagram alir berikut:

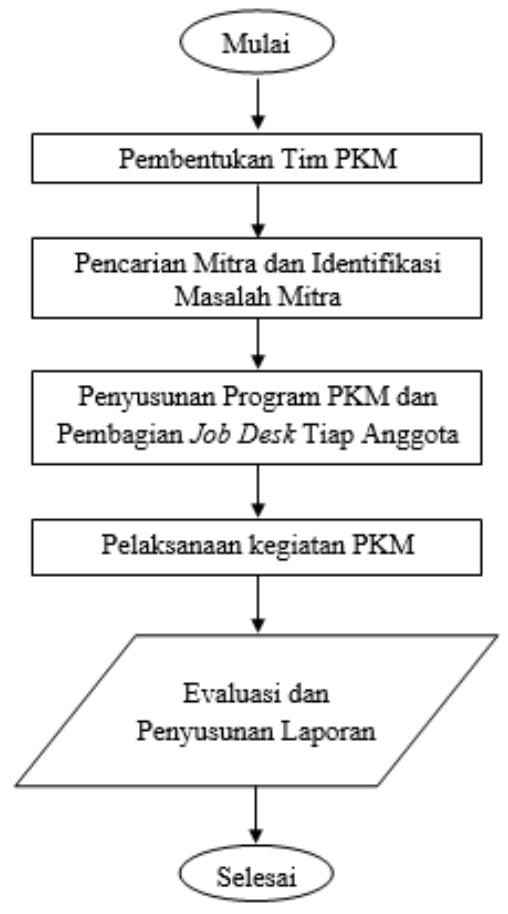

Gambar 1. Diagram Alir Kegiatan 


\section{HASIL DAN PEMBAHASAN}

Kegiatan Program Kemitraan Masyarakat ini diawali dengan survei pendahuluan pada Bulan Maret 2019. Dari hasil survei tersebut, kemudian dilakukan analisis untuk menentukan kebutuhan mitra. Setelah kebutuhan mitra ditentukan, disusun skenario kegiatan serta dipersiapkan semua bahan dan perlengkapan yang akan digunakan untuk kegiatan edukasi. Kegiatan edukasi dimulai dengan sambutan dari Kepala Sekolah MTs Nurul Qur'an dan Ketua Tim PKM STT-PLN.

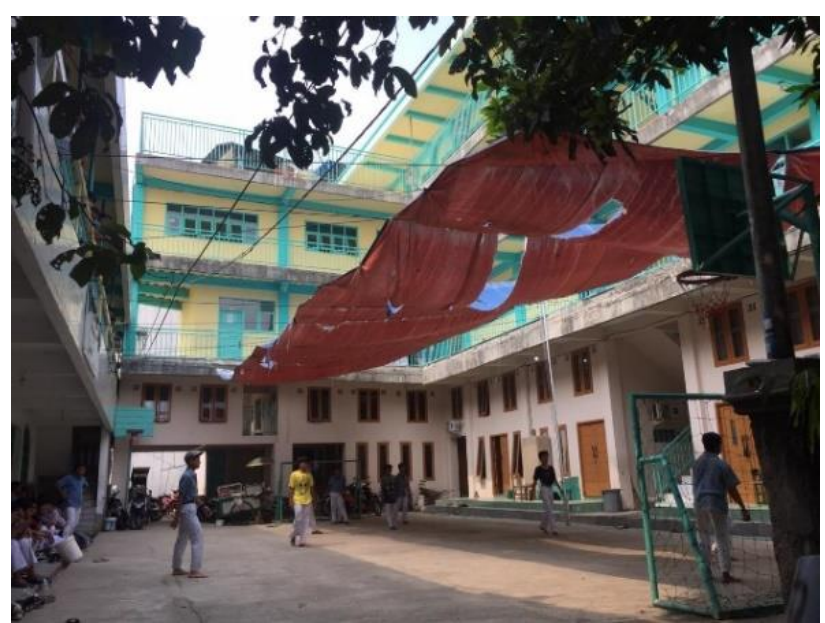

Gambar 2. Sekolah MTs Nurul Qur’an Sebagai Mitra PKM

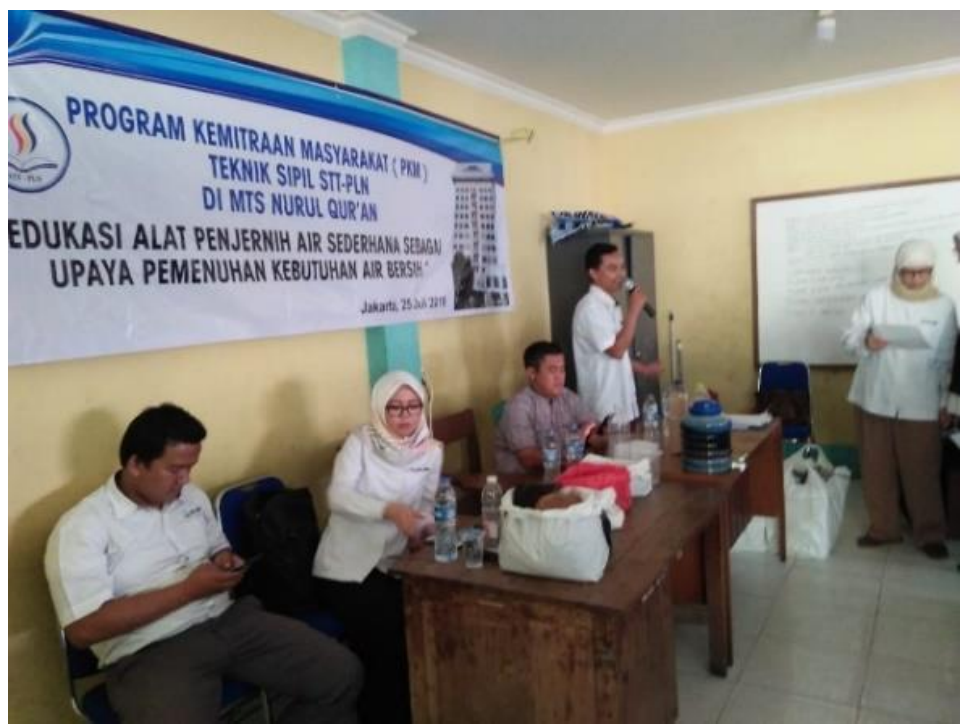

Gambar 3. Sambutan Ketua Tim PKM

Setelah itu, dilanjutkan dengan kegiatan pretest yang dilakukan oleh siswa dan siswi MTs Nurul Qur'an. Kegiatan selanjutnya adalah pemaparan materi tentang edukasi penjernihan air dan melakukan praktek pembuatan alat penjernih air sederhana bersama pesertayang disampaikan oleh Tim PKM STT-PLN. Setelah penyampaian materi edukasi selesai dilakukan kembali kegiatan posttest yang dilakukan oleh siwa dan siswi MTs Nurul Qur'an.

Sebelum diadakan kegiatan edukasi alat penjernih air sederhana sebagai upaya pemenuhan kebutuhan air bersih, siswa dan siswi MTs Nurul Qur'an belum memahami secara menyeluruh 
mengenai proses penjernihan air keruh bersih berkaitan dengan teknik filtrasi menggunakan media penyaringan sehingga didapatkan air bersih yang dapat dimanfaatkan untuk kehidupan sehari-hari.

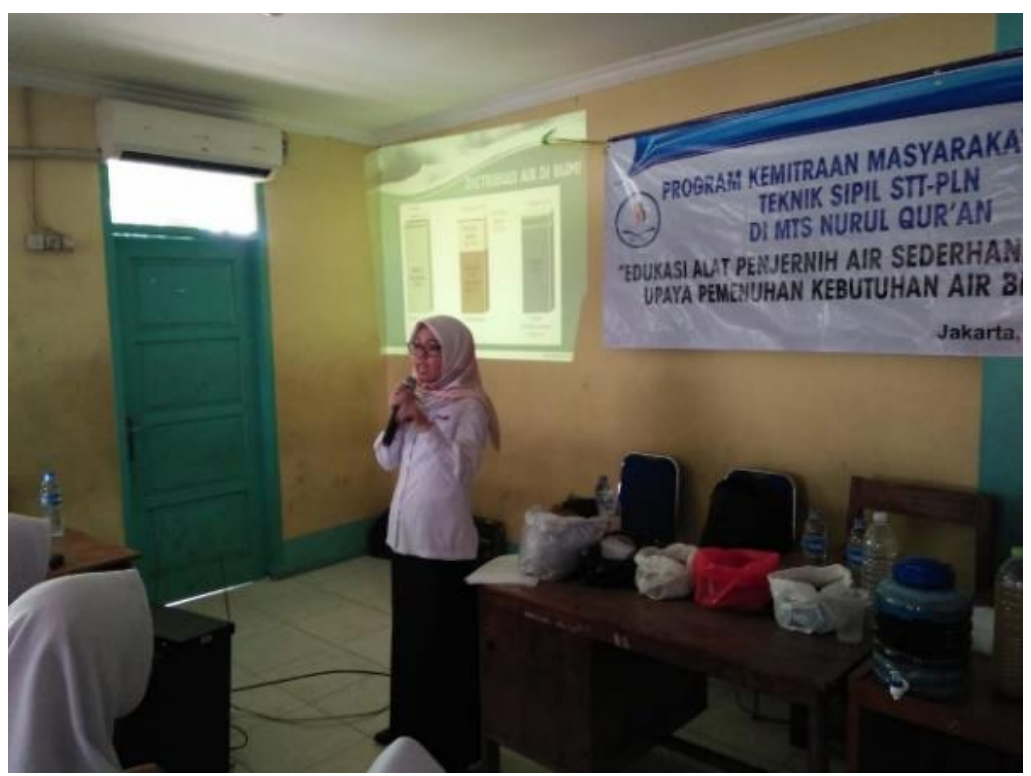

Gambar 4. Pemaparan Materi

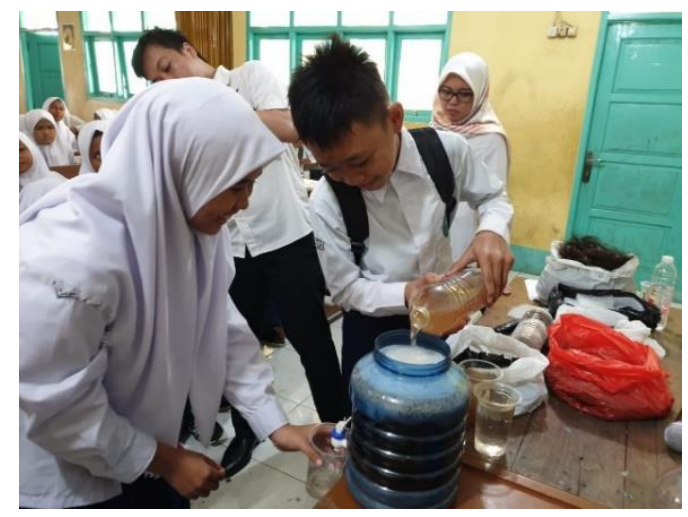

Gambar 5. Alat Penjernih Air Sederhana

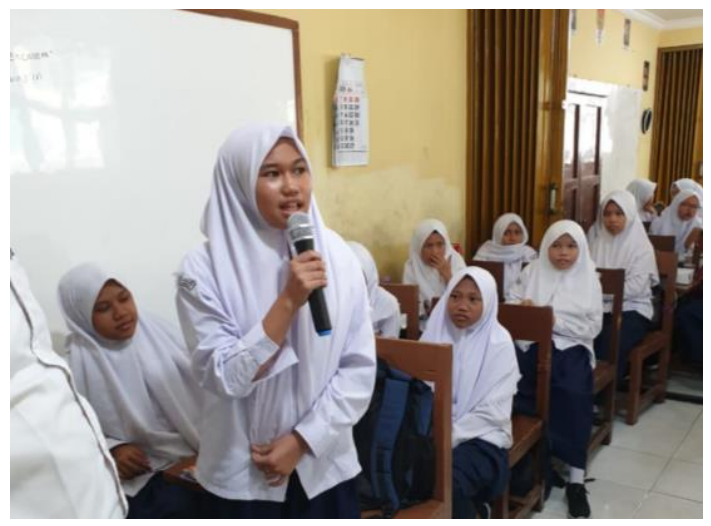

Gambar 6. Sesi Tanya Jawab 


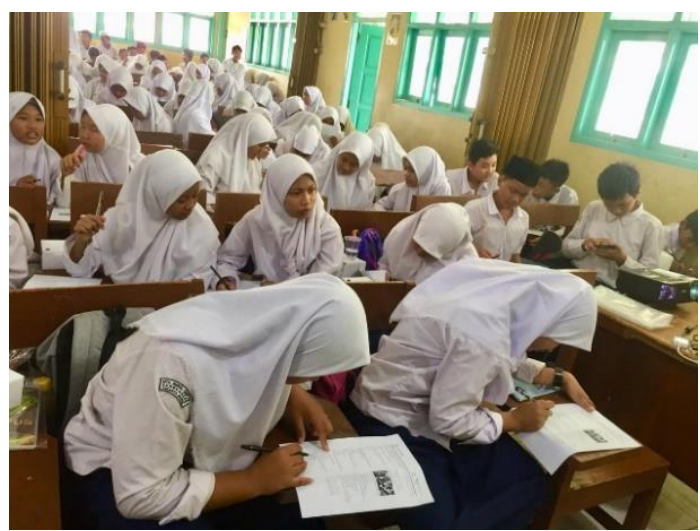

Gambar 7. Pelaksanaan Pre Test dan Post Test

Setelah dilakukan edukasi, siswa dan siswi MTs Nurul Qur'an mulai memiliki pengetahuan mengenai proses penjernihan air dengan teknik filtrasi, alat dan bahan yang digunakan, prosedur kerja, serta mengetahui hasil akhir penjernihan air. Hal ini dapat terlihat dari hasil pretest dan posttest yang dilakukan pada kegiatan edukasi yang mengalami kenaikan sehingga menunjukkan adanya peningkatan pengetahuan siswa dan siswi MTs Nurul Qur'an. Dari 95 siswa dan siswi yang mengikuti edukasi, sebelum diberikan edukasi nilai rata-rata pretest sebesar 2,9 sedangkan setelah diberikan edukasi nilai rata-rata posttest sebesar 6,8 . Hasil pretest dan posttest tentang pengetahuan alat penjernih air sederhana dapat dilihat pada Tabel 2 dan Gambar 8.

Tabel 2. Hasil Nilai PreTest dan Post Test

\begin{tabular}{|c|c|c|c|}
\hline \multicolumn{2}{|c|}{ HASIL NILAI PRETEST } & \multicolumn{2}{c|}{ HASIL NILAI POST TEST } \\
\hline Nilai & $\begin{array}{c}\text { Jumlah Siswa } \\
\text { (orang) }\end{array}$ & Nilai & $\begin{array}{c}\text { Jumlah Siswa } \\
\text { (orang) }\end{array}$ \\
\hline 0 & 4 & 0 & 0 \\
\hline 1 & 17 & 1 & 0 \\
\hline 2 & 21 & 2 & 0 \\
\hline 3 & 24 & 3 & 5 \\
\hline 4 & 15 & 5 & 7 \\
\hline 5 & 8 & 6 & 17 \\
\hline 6 & 4 & 7 & 19 \\
\hline 7 & 0 & 8 & 11 \\
\hline 8 & 2 & 9 & 4 \\
\hline 9 & 0 & 10 & Nilai Rata-Rata Post Test $=\mathbf{6 , 8}$ \\
\hline 10 & 0 & \multicolumn{2}{|c|}{} \\
\hline \multicolumn{2}{|c|}{ Nilai Rata-Rata PreTest $=\mathbf{2 , 9}$} & & 9 \\
\hline
\end{tabular}

(Sumber: Hasil Analisis) 


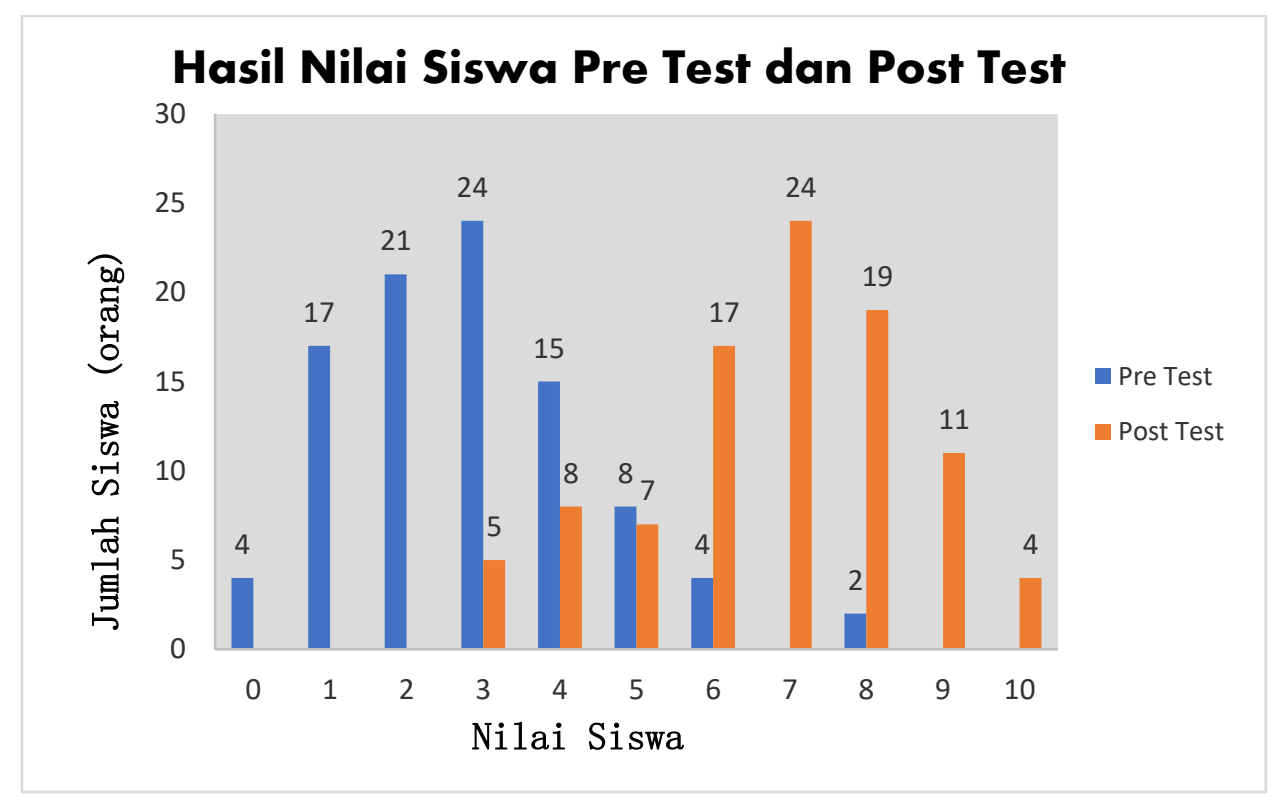

Gambar 8. Grafik Hasil PreTest dan Post Test

Selama kegiatan berlangsung, terlihat antusias peserta yang cukup besar. Hal ini tampak dari semangat para peserta selama sesi pemaparan materi, ikut serta dalam praktek, serta adanya timbal balik dari peserta pada sesi tanya jawab.

Melalui kegiatan edukasi ini dapat disimpulkan bahwa MTs Nurul Qur'an telah memahami pentingnya pengetahuan mengenai proses penjernihan air dengan teknik filtrasi sebagai upaya pemenuhan kebutuhan air bersih dalam kehidupan sehari-hari.

\section{KESIMPULAN DAN SARAN}

Setelah kegiatan sosialisasi dan edukasi terlaksana, beberapa hal yang telah dicapai adalah peserta memahami pembagian dan macam-macam air di bumi, karakteristik air bersih, dan teknik pengolahan air, memahami standar baku persyaratan kualitas air bersih, memahami proses penjernihan air dengan teknik filtrasi menggunakan media penyaringan, fungsi dan manfaat dari alat penjernih air sederhana dalam kehidupan sehari-hari, memahami alat dan bahan yang digunakan dalam pembuatan alat penjernih air sederhana, langkah-langkah dalam proses pembuatan alat penjernih air sederhana, serta dapat membandingkan hasil sebelum dan setelah air dijernihkan dengan alat penjernih air sederhana.

Saran dalam kegiatan PKM ini adalah diharapkan kegiatan serupa dapat diadakan tidak hanya di lingkungan sekitar kampus STT-PLN, mengingat pengetahuan penjernihan air sebagai upaya pemenuhan kebutuhan air bersih. Kemudian adanya kegiatan lanjutan berupa pembahasan mengenai uji laboratorium mengenai kelayakan hasil penjernihan air untuk kebutuhan air minum.

\section{UCAPAN TERIMAKASIH}

Penulis mengucapkan terima kasih kepada STT-PLN, MTs Nurul Qur'an, dan seluruh dosen Teknik Sipil terlibat yang telah memberi dukungan dalam membantu pelaksanaan kegiatan program kemitraan masyarakat. Apabila terdapat banyak kekurangan dalam artikel ini peulis memohon maaf atas kekurangan tersebut. Semoga artikel ini dapat bermanfaat bagi para pembaca. 


\section{DAFTAR PUSTAKA}

[1] Air Bersih dan Kehidupan Manusia | WWF Indonesia, https://www.wwf.or.id/?26120/ AirBersih-dan-Kehidupan-Manusia, diakses tanggal 3 Maret 2019.

[2] Pebrianty, Friska, dkk., (2016), Modul Penyaringan Air Sederhana, Fakultas Teknik Universitas Lambung Mangkurat, Banjarmasin.

[3] Peraturan Menteri Kesehatan, (1990), Nomor: 416/Menkes/Per/IX/1990: Syarat-Syarat dan Pengawasan Kualitas Air.

[4] Suarda M, Dana, I. W., 2010, Perencanaan Penyaring Air Sederhana Untuk Sistem Air Bersih Pedesaan, Universitas Udayana, Denpasar. 